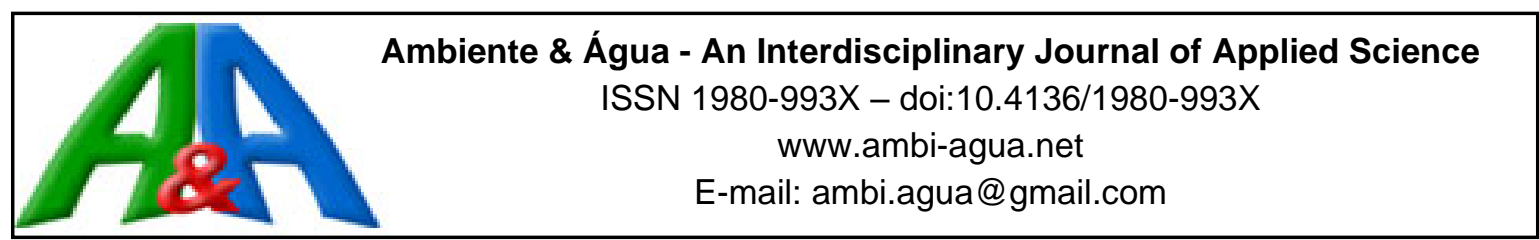

\title{
Aquatic entomofauna and biotic index along the Pindo Grande River, Montano Bajo Forest, in Pastaza Province, Ecuador
}

\author{
ARTICLES doi:10.4136/ambi-agua.2563
}

Received: 21 Apr. 2020; Accepted: 03 Nov. 2020

\begin{abstract}
Maria Alexandra Endara1 ${ }^{1}$; Demián Hinojosa-Garró ${ }^{2 *}$
${ }^{1}$ Departamento de Ingeniería Ambiental. Universidad Tecnológica Equinoccial (UTE), Avenida Mariscal Sucre, s/n, y Mariana de Jesús, Quito, Ecuador. E-mail: maria.endara@ute.edu.ec ${ }^{2}$ Centro de Estudios en Desarrollo Sustentable y Aprovechamiento de la Vida Silvestre (CEDESU). Laboratorio en Ecología Acuática y Monitoreo Ambiental. Universidad Autónoma de Campeche, Avenida Héroe de Nacozari, n480, 4079, San Francisco de Campeche, Campeche, México.

*Corresponding author. E-mail: dhinojos@uacam.mx
\end{abstract}

\begin{abstract}
Pindo Grande River water quality was analyzed during rainy seasons of 2014 and 2017 and dry seasons of 2015 and 2016. Specimens were collected using surber net, kick net and manual stone collection, from five different sites along the river. In the laboratory, specimens were identified to the lowest possible taxonomic level. Taxon richness, abundance, diversity, trophic niches, and Biological Monitoring Working Party for Colombia (BMWP/Col) index were assessed. A total of 1,695 specimens belonging to 95 taxa were collected, including 57 taxa in rainy seasons and 38 taxa in dry seasons. Class Insecta was the most abundant (98.6\%). Richness was highest $(3,427)$ at M1000 collection sites in rainy and dry seasons and varied from moderate to high (13-35) at other sites. All sampling sites had medium diversity, and organisms belonged to three trophic categories: herbivores, detritivores, and predators. Environmental water quality was medium at most sites $(\mathrm{BMWP} / \mathrm{Col}=102-150)$. All sites exhibited good conservation status $(\mathrm{BMWP} / \mathrm{Col}=192-152)$ in the rainy season; only two sites presented medium conservation status $(B M W P / c o l=93-67)$ in the dry season. Principal component analysis indicated that main variables associated with sites were $\mathrm{NO}_{3}$ and COD in upstream areas in the rainy season and $\mathrm{O}_{2}$ in the dry season. Downstream areas were grouped based on depth and width of the river in the rainy season and on $\mathrm{pH}, \mathrm{PO}_{4}$, and conductivity in the dry season. According to analysis, the Pindo Grande River has preserved epibenthic communities; it is an oxygenated stream, but its habitats have been gradually affected by anthropogenic activities.
\end{abstract}

Keywords: diversity, environmental conditions, macroinvertebrates.

\section{Entomofauna aquática e índice de qualidade biótica do Rio Pindo Grande, Floresta Montano Baixo Pastaza - Equador}

\section{RESUMO}

A comunidade de macroinvertebrados aquáticos do Rio Pindo Grande foi analisada, na época chuvosa de 2014 e 2017; e época seca de 2015 e 2016, na Estação Biológica Pindo Mirador. Os Macroinvertebrados foram coletados com rede Surber, rede de chute e coleta manual, em cinco pontos ao longo do rio. No laboratório, eles foram identificados até o menor 
nível taxonômico possível. Calculou-se: riqueza (S), abundância, diversidade ( $\left.\mathrm{H}^{\prime}\right)$, níveis tróficos e índice BMWP/Col. Foram coletados 1695 indivíduos pertencentes a 95 espécies; 57 na estação chuvosa e 38 na estação seca. A classe Insecta abrangeu a maioria dos organismos (98.6\%). O ponto M1000 teve maior riqueza (34-27 espécies) nas duas épocas climáticas, enquanto os pontos restantes apresentaram valores que flutuavam de moderado a alto (13-35 espécies). Todos os pontos obtiveram média diversidade e organismos distribuídos em três categorias tróficas: herbívoros, detritívoros y predadores. A maioria dos locais tinha média qualidade (BMWP/Col s 102-150). Na estação chuvosa, todos os sítios obtiveram um bom estado de conservação (BMWP / Col 192-152), enquanto, na estação seca, apenas dois locais tinham médio estado de conservação (BMWP/Col 93-67). A Análise de Componentes Principais (ACP), determinou que as variáveis primárias associadas aos locais foram: a montante em época de chuvas de $\mathrm{NO}_{3}$ e DQO, na estação seca o $\mathrm{O}_{2}$. Os locais rio abaixo na estação chuvosa, foram agrupados com base na profundidade e largura do rio, em tempo seco $\mathrm{PH}, \mathrm{PO}_{4}$ e condutividade. Se determinou uma comunidade macro-bentônica saudável e variação, frente as atividades antrópicas.

Palavras-chave: condição ambiental, diversidade, macroinvertebrados.

\section{INTRODUCTION}

Benthic macroinvertebrates represent one of the most suitable groups for the purposes of evaluating the quality of aquatic ecosystems, due to their ubiquity as a functional feeding group and the ability of some groups to withstand hypoxic conditions (López-López and Sedeño-Díaz, 2015). They may be particularly powerful indicators of water quality, as they are not difficult to distinguish in the laboratory, are present throughout all seasons, frequently live for more than one year, have restricted mobility, and are integrators of ecological conditions (Plafkin et al., 1989; Khatri and Tyagi, 2015).

Disturbance through variable flow regimes is a prime factor controlling macroinvertebrate communities in running water (Stanford and Ward, 1983; Reice et al., 1990). Tropical streams are generally highly influenced by regular floods (Covich, 1988). Jacobsen and Encalada (1998) suggested that flow related instability of tropical Andes streams was the main feature structuring the invertebrate fauna, while other site characteristics were less important. In addition, Bojsen and Jacobsen (2003) found that the total macroinvertebrate density generally differed between wet and dry seasons.

There are several studies that have used macroinvertebrate communities to assess the effect of organic waste on the coastal streams of South American countries (Selvanayagam and Abril, 2015). Most of them have been carried out in Colombia, Chile, Argentina, Uruguay, Peru, Brazil, and Bolivia but only a few in Ecuador and none in its tropical coastal streams (Selvanayagam and Abril, 2015). Therefore, data on the current status of lotic water bodies and discussions about their conservation are limited.

The Biological Monitoring Working Party for Colombia (BMWP/Col) index (Roldán, 2003) has shown that it is ideal for determining water quality in foothill ecosystems, as more than $97 \%$ of the recorded macroinvertebrate families are included in this index (Arroyo and Encalada, 2009).

The Pindo Grande River supplies drinking water to thousands of families. Water from this river is treated and distributed to approximately 1,350 homes in Cantón Mera and 3,750 homes in Canton Pastaza (Torres, 2006). Despite its importance to local communities, this river has been severely affected by deforestation, cultivation of Naranjilla (Solanum quitoense) and babaco (Carica pentagona) crops (Ríos and Borgtoft, 1994; Rivas, 2015), and cattle farming in the vicinity of the riverbed (Torres, 2006). 
To assess changes in functional structure and facilitate disentangling the effects of disturbance on macroinvertebrate communities in the Ecuadorian Amazon Region, the quality of the Pindo Grande River water around Pindo Mirador Biological Station was studied using macroinvertebrate-based bioassessments (BMWP/Col) for two seasons (wet and dry). The results are expected to serve as the basis for conservation and management strategies of these water sources by the local authorities and residents.

\section{MATERIALS AND METHODS}

\subsection{Study site}

The Pindo Grande River is located in Pastaza Province, Cantón Mera, Ecuador, in the northwestern region of Pastaza Province, eastern Ecuador (Rageot and Albuja, 1994). This river, situated at the eastern foothills of the Andes, in the Habitagua Protective Forest and Vegetation sector 2,800 m above sea level, traverses Cantón Mera and Pastaza and flows into the Puyo River, in the Unión Base sector, and along with the Alpayacu and Tashupi Rivers, forms the smaller tributaries of the Pastaza River Basin, occupying an area of $160,688 \mathrm{~km}^{2}$ (Pastaza, 2015). The annual rainfall ranges from 1,500 to 4,000 $\mathrm{mm}$, with the highest rainfall recorded in July and August. The temperature varies from 20 to $25^{\circ} \mathrm{C}$, with a relative humidity of $86 \%$ (UTE, 2015). The study area along the river was located 1100-1200 m above sea level, and sampling was conducted during the rainy (July 2014 and May 2017) and dry (February 2015 and August 2016) seasons, at five collection sites located along the ecological gradient of the river and included crops, pastures, and a preserved forest. The selection of the sampling points along the river was made based on changes in riparian vegetation, riverbank substrate and composition, as well as human activities. The coordinates and altitudes were recorded using a GPS (Garmin, Oregon 550, USA). Figure 1:

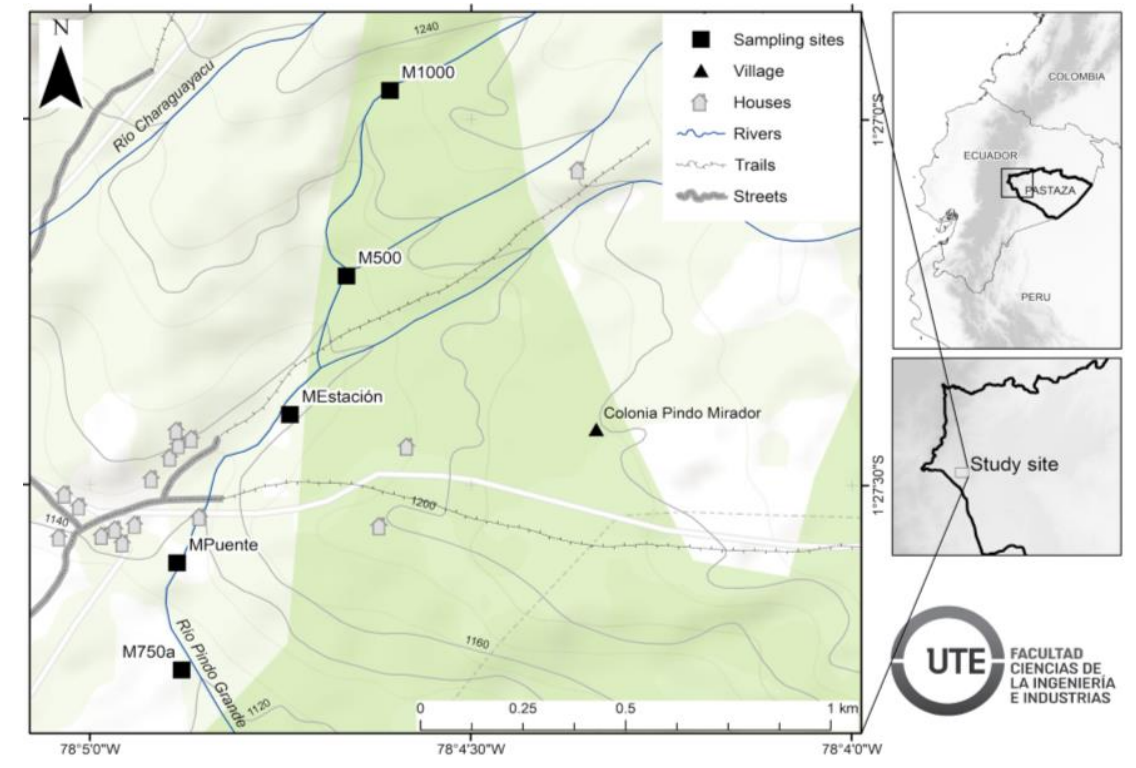

Figure 1. Study area and sampling sites at the lower basin of the Pindo Grande River, Ecuador.

M1000 (01 $\left.26^{\prime} 57.624^{\prime \prime} \mathrm{S} / 78^{\circ} 04^{\prime} 36.4651^{\prime \prime} \mathrm{W}\right)$ sandy substrate with stones, gravel and little detritus; moderately torrential, transparent waters, with $20 \mathrm{~m}$ tall trees, bushes and ferns.

M500 (01 $\left.{ }^{\circ} 27^{\prime} 12.8514^{\prime \prime} \mathrm{S} / 78^{\circ} 04^{\prime} 39.8714^{\prime \prime} \mathrm{W}\right)$ sandy substrate with stones, small rocks and detritus; moderately torrential, clear waters. Vegetation that covers the riverbank has $30 \mathrm{~m}$ high trees, shrubs, ferns and herbaceous plants. One hundred meters below there is a water catchment infrastructure. 
Mestación ( $\left.01^{\circ} 27^{\prime} 24.2418^{\prime \prime} \mathrm{S} / 7^{\circ} 04^{\prime} 44.317^{\prime \prime} \mathrm{W}\right)$, sandy benthos with stones, small rocks, gravel, fallen logs and little detritus, torrential flow with transparent waters. Shore banks have secondary vegetation, composed of ornamental plants, small shrubs, grass, and small trees (10 $\mathrm{m})$ with few epiphytes.

Mpuente (0127'36.4187" S / 7804'53.1894" W), sandy-clayey benthos with stones covered with brown algae, few rocks and gravel; moderately torrential, slightly cloudy waters. Shore banks have crops of wild cane, small palms, few trees and shrubs. People from the surrounding communities walk across the bridge.

M750a (0127'45.2007" S / 78 04'52.8225" W), sandy-clayey benthos with stones covered with brown algae and gravel; torrential flow, slightly cloudy waters. Both shores have wild cane crops, small palms, few trees and shrubs. There are houses and farms around the river.

\subsection{Field study}

Ten collection points were established at random, at each sampling site, a $50 \mathrm{~m}$ long transect was established parallel to the river bank. Macroinvertebrates were collected for $1 \mathrm{~min}$, simultaneously using a surber net (Garie and McIntosh, 1986; Roldán, 1988), kick net (Roldán, 1988), and manual stone collection (Walteros-Rodriguez and Paiba-Alzate, 2010), to cover all possible microhabitats and associated species (Abarca Morales, 2007). The collected organisms were transferred to plastic bags with $70 \%$ ethanol (Jacobsen and Encalada, 1998), which were then sealed (Muzaffar and Colbo, 2002) and labeled for later identification in the laboratory.

At each sampling site, the width and depth of the river were measured using a $50 \mathrm{~m} \mathrm{TP}$ 50ME fiberglass measuring tape (Truper). The $\mathrm{pH}$, temperature, conductivity, and dissolved oxygen were determined in situ during the second sampling period (August 2016 and May 2017), using a multiparameter equipment (HQ40d, HACH, USA). Chemical oxygen demand (COD), 5-day biochemical oxygen demand ( $\left.\mathrm{BOD}_{5}\right), \mathrm{PO}_{4}$, and $\mathrm{NO}_{3}$ were also determined for this sampling period, using a spectrophotometer (DR 2800, HATCH, USA), at the UTE University Environmental Engineering Laboratory.

Table 1 shows the parameters analyzed and the methods used by the Standard Methods for the Examination of Water and Wastewater and the Alpha American Water Works Association.

Table 1. Methods used to analyze chemicals and nutrients, and the associated references.

\begin{tabular}{ccc}
\hline Parameters & Units & Method \\
\hline Temperature & ${ }^{\circ} \mathrm{C}$ & APHA- 5550 B \\
pH & & HACH-8156 \\
Conductivity & $\left(\mu \mathrm{S} / \mathrm{cm}^{2}\right)$ & HACH-8160 \\
$\mathrm{COD}$ & $(\mathrm{mg} / \mathrm{L})$ & HACH-800 \\
$\mathrm{BOD}_{5}$ & $(\mathrm{mg} / \mathrm{L})$ & APHA-5210 D \\
$\mathrm{PO}_{4}$ & $(\mathrm{mg} / \mathrm{L})$ & HACH-8190 \\
Nitrates & $(\mathrm{mg} / \mathrm{L})$ & HACH-8507 \\
\hline
\end{tabular}

\subsection{Laboratory analyses}

In the laboratory, the collected specimens were separated from the substrate, first using a sieve and then with tweezers, and were then washed with water and $70 \%$ ethanol. Separated specimens were then transferred to $3 \mathrm{~mL}$ test tubes (smaller specimens) or $100 \mathrm{~mL}$ plastic bottles (larger specimens).

Macroinvertebrates were identified to the lowest possible taxonomic level, using a binocular stereoscopic microscope (ZM-AB-ST2; 10. ocular, 1. and 4. objective), and dichotomous keys (Merrit et al., 2008; Roldán, 1988; Fernández and Domínguez, 2001; Roldán, 
2003; Salles, 2006; Domínguez and Fernández, 2009; Hamada et al., 2014). Identified specimens were deposited following the specimen preservation protocol of the Zoology Museum of the Pontifical Catholic University of Ecuador Patent No. 11-2016-FAU-DPAP-MA and Collection No. QCAZI 214 831-214886.

\subsection{Data analyses}

Total species richness was calculated using an abundance estimator (Jackknife 1), with 100 randomizations, in EstimateS Version 8.20. Richness $(\mathrm{S})$, abundance $(\mathrm{N})$, and relative abundance (\%) were also calculated (Carrera and Fierro, 2001; Moreno, 2001). The ShannonWiener index was calculated using BIODAP software (Moreno, 2001). Trophic niches were classified into three categories: herbivores, detritivores, and predators (Chará-Serna et al., 2010). The BMWP/Col. index (Roldán, 1988) and Sorensen's (qualitative) similarity coefficient (Magurran, 1988) were used to assess water quality. Principal Component Analysis (PCA) was used as a method to cluster sites according to shared physicochemical characteristics.

\section{RESULTS}

\subsection{Physicochemical parameters}

The physicochemical parameters analyzed at the sampling sites in August 2016 and May 2017 are shown in Table 2. Physicochemical data for the study sites were classified as either upstream or downstream from the MEstación site during the dry and rainy seasons, using principal component analysis (PCA). PCA classified M1000 and M500 as upstream and downstream, respectively, and healthy environments, whereas MEstación, MPuente, and ME750a were classified as downstream and disrupted environments, in both sampling seasons. PCA explained $73 \%$ of data variance. The sampling sites were grouped into upstream or downstream by season (Figure. 2). $\mathrm{NO}_{3}$ and $\mathrm{COD}$ were associated with upstream areas in the rainy season, while $\mathrm{O}_{2}$ in the dry season. In contrast, the downstream areas were grouped based on the depth and width of the river in the rainy season, and on $\mathrm{pH}, \mathrm{PO}_{4}$, and conductivity variations in the dry season (Figure 2).

Table 2. Physicochemical characteristics of the water column at the five sampling sites along the Pindo Grande River in the rainy and wet seasons.

\begin{tabular}{|c|c|c|c|c|c|c|c|c|c|c|}
\hline \multirow{2}{*}{$\begin{array}{c}\text { Physicochemical } \\
\text { parameter }\end{array}$} & \multicolumn{5}{|c|}{ Rainy season (2017) } & \multicolumn{5}{|c|}{ Dry season (2016) } \\
\hline & M100 & M500 & $\begin{array}{c}\text { M } \\
\text { estación }\end{array}$ & $\begin{array}{c}\mathrm{M} \\
\text { puente }\end{array}$ & M750a & M100 & M500 & $\begin{array}{c}\text { M } \\
\text { estación }\end{array}$ & $\begin{array}{c}\mathrm{M} \\
\text { puente }\end{array}$ & M750a \\
\hline $\mathrm{pH}$ & 6.5 & 6.5 & 6.5 & 5.7 & 6.5 & 7.0 & 7.0 & 8.0 & 8.0 & 8.0 \\
\hline $\begin{array}{c}\text { Temperature } \\
\left({ }^{\circ} \mathrm{C}\right)\end{array}$ & 19.7 & 19.5 & 19.6 & 19.8 & 19.8 & 20.6 & 20.6 & 20.7 & 20.7 & 20.7 \\
\hline $\begin{array}{l}\text { Conductivity } \\
\left(\mu \mathrm{S} / \mathrm{cm}^{2}\right)\end{array}$ & 41.7 & 47.7 & 42.7 & 54.5 & 54.5 & 43.6 & 43.6 & 52.7 & 52.1 & 52.1 \\
\hline $\begin{array}{c}\text { Dissolved } \mathrm{O}_{2} \\
(\mathrm{mg} / \mathrm{L})\end{array}$ & 7.4 & 7.4 & 7.12 & 7.15 & 7.15 & 8.3 & 8.3 & 7.39 & 7.65 & 7.65 \\
\hline $\mathrm{COD}(\mathrm{mg} / \mathrm{L})$ & 47 & 47 & 11 & 4 & 4 & 65 & 65 & 14 & 2 & 2 \\
\hline $\mathrm{BOD}_{5}(\mathrm{mg} / \mathrm{L})$ & 7.16 & 7.16 & 5.57 & 6.47 & 6.47 & 6.16 & 6.16 & 6.88 & 6.37 & 6.37 \\
\hline $\mathrm{PO}_{4}(\mathrm{mg} / \mathrm{L})$ & 0.078 & 0.078 & 0.112 & 0.436 & 0.436 & 0.083 & 0.083 & 0.090 & 0.514 & 0.514 \\
\hline Nitrates $(\mathrm{mg} / \mathrm{L})$ & 0.313 & 0.313 & 0.310 & 0.021 & 0.021 & 0.241 & 0.241 & 0.270 & 0.011 & 0.011 \\
\hline
\end{tabular}

Source: Vinueza (2017). COD, chemical oxygen demand; BOD $_{5}$, 5-day biochemical oxygen demand. 


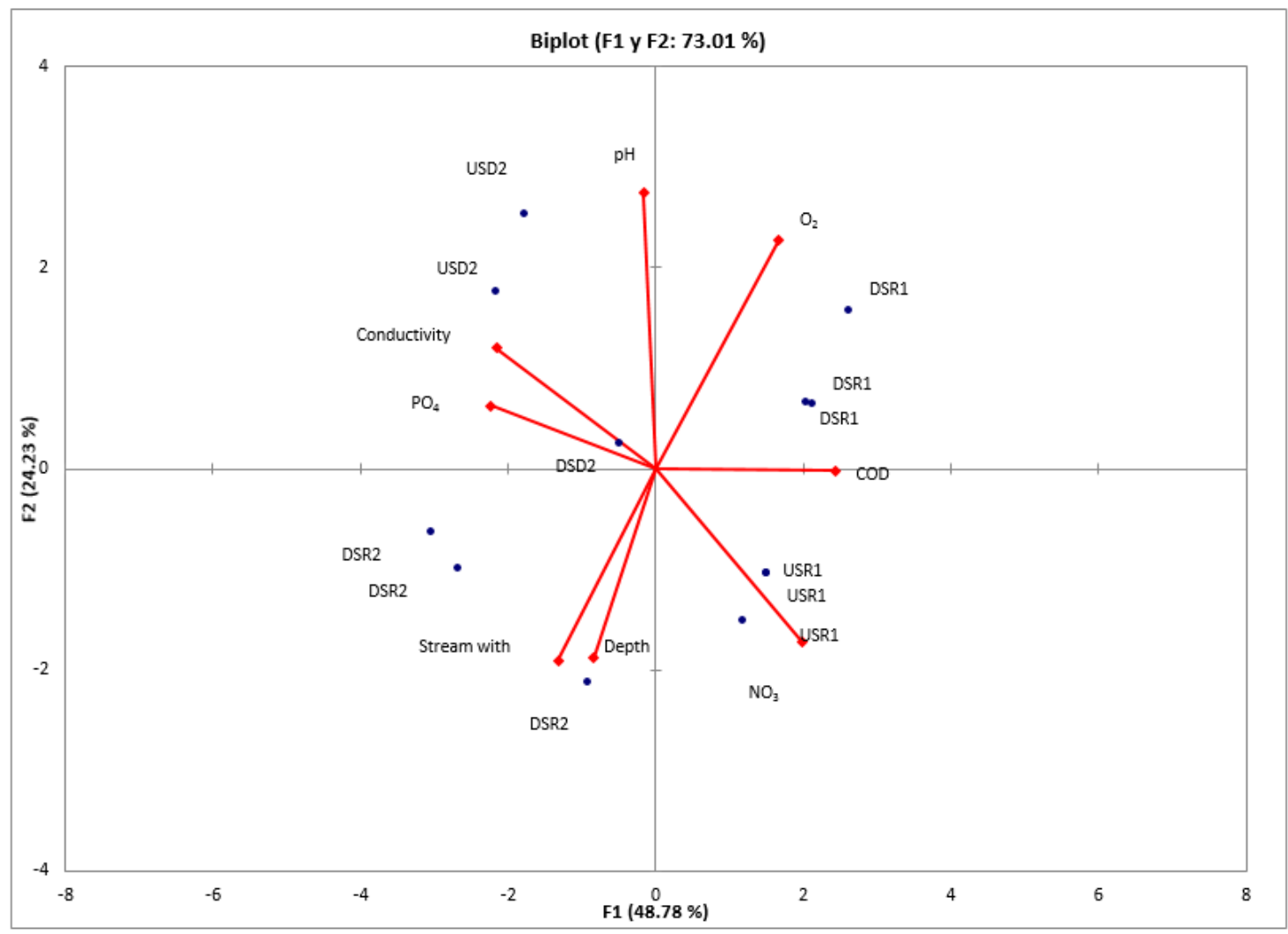

Figure 2. Principal Component Analysis (PCA) for the main physicochemical variables recorded at the sampling sites in the Pindo Grande River. USR= upstream rains, DSR = downstream rains, USD = upstream dry, DSD = downstream dry. $1=1$ st year sampling and 2 $=2$ nd year sampling.

\subsection{Taxon richness, abundance, and diversity}

A total of 1,052 individuals were collected during the rainy season, belonging to four classes, 12 orders, 36 families, and 57 morphospecies. Class Insecta represented $98.6 \%$ of the total sample, with order Trichoptera being the most abundant (478 individuals, and order Lepidoptera being the least abundant (three individuals, 0.29\%). Classes Arachnida, Crustacea, and Tricladida were rare, represented by only one taxon each, with a few, 1, and 13 individuals, respectively (Table 3 ).

In the dry season, 643 individuals were collected, and classified into two classes, 10 orders, 24 families, and 38 morphospecies. Class Insecta comprised $98.5 \%$ of the total sample, with order Ephemeroptera being the most abundant, whereas class Tricladida was represented by only one taxon $(0.16 \%)$ with 10 individuals (Table 4). Genus Rhagovelia of family Veliidae was the most abundant in the rainy season, whereas genus Thraulodes of family Leptophlebiidae was the most abundant in the dry season.

Richness at the sampling points ranged from 21 to 35 taxa in the rainy season (Table 3 ), and from 13 to 27 taxa in the dry season (Table 4). The comparison of the curve of total sampled morphospecies (57 and 38) at the two time points with the curve estimated using Jackknife 1 (75 and 50) indicated that the sampling effort, using the three methodologies (Surber net, kick net, and manual stone collection), resulted in $76 \%$ of the local aquatic macroinvertebrate richness being collected.

The Shannon-Wiener index values at M1000, M500, and MEstación were intermediate in the rainy season, corresponding to $2.53,2.58$, and 2.38 , respectively. The sampling sites with the highest and lowest Shannon-Wiener index values were M750a (2.97) and MPuente (2.26), respectively (Figure 3). 
Table 3. Abundance of different taxa collected during the rainy season of 2014 and 2017 at the five sampling sites along the Pindo Grande River, Pastaza Province, Ecuador.

\begin{tabular}{|c|c|c|c|c|c|c|c|}
\hline \multirow{2}{*}{ Family } & \multicolumn{7}{|c|}{ Rainy season } \\
\hline & M1000 & M500 & MEstación & MPuente & M750a & Total & $\%$ \\
\hline Lymnessiidae & 1 & 0 & 0 & 0 & 0 & 1 & 0.1 \\
\hline Palaemonidae & 0 & 1 & 0 & 0 & 0 & 1 & 0.1 \\
\hline Blattidae & 0 & 0 & 0 & 0 & 0 & 0 & 0 \\
\hline Elmidae & 13 & 6 & 9 & 1 & 17 & 46 & 4.4 \\
\hline Psephenidae & 9 & 18 & 14 & 5 & 11 & 57 & 5.4 \\
\hline Ptilodactylidae & 21 & 13 & 13 & 7 & 8 & 62 & 5.9 \\
\hline Scirtidae & 0 & 1 & 0 & 0 & 0 & 1 & 0.1 \\
\hline Chironomidae & 0 & 0 & 0 & 46 & 1 & 47 & 4.5 \\
\hline Simuliidae & 0 & 1 & 1 & 1 & 0 & 3 & 0.3 \\
\hline Tipulidae & 0 & 1 & 1 & 47 & 1 & 50 & 4.8 \\
\hline Baetidae & 21 & 16 & 15 & 101 & 10 & 163 & 15.5 \\
\hline Euthyplociidae & 7 & 0 & 0 & 0 & 0 & 7 & 0.7 \\
\hline Leptohyphidae & 28 & 17 & 16 & 148 & 11 & 220 & 20.9 \\
\hline Leptophlebiidae & 56 & 33 & 31 & 249 & 21 & 390 & 37.1 \\
\hline Corixidae & 0 & 0 & 0 & 0 & 1 & 1 & 0.1 \\
\hline Gerridae & 0 & 0 & 0 & 0 & 5 & 5 & 0.5 \\
\hline Naucoridae & 0 & 0 & 0 & 0 & 6 & 6 & 0.6 \\
\hline Veliidae & 1 & 0 & 0 & 1 & 34 & 36 & 3.4 \\
\hline Pyralidae & 1 & 2 & 0 & 0 & 0 & 3 & 0.3 \\
\hline Corydalidae & 8 & 0 & 0 & 2 & 4 & 14 & 1.3 \\
\hline Coenagrionidae & 3 & 2 & 3 & 1 & 2 & 11 & 1.0 \\
\hline Gomphidae & 1 & 0 & 0 & 0 & 0 & 1 & 0.1 \\
\hline Libellulidae & 4 & 2 & 3 & 1 & 2 & 12 & 1.1 \\
\hline Megapodagrionidae & 5 & 2 & 3 & 1 & 2 & 13 & 1.2 \\
\hline Platystictidae & 5 & 0 & 0 & 0 & 0 & 5 & 0.5 \\
\hline Polythoridae & 6 & 2 & 1 & 1 & 0 & 10 & 1.0 \\
\hline Perlidae & 7 & 1 & 4 & 0 & 3 & 15 & 1.4 \\
\hline Calamoceratidae & 11 & 4 & 3 & 0 & 0 & 18 & 1.7 \\
\hline Helicopsychidae & 1 & 0 & 23 & 1 & 2 & 27 & 2.6 \\
\hline Hydrobiosidae & 0 & 1 & 0 & 0 & 0 & 1 & 0.1 \\
\hline Hydropsychidae & 12 & 5 & 26 & 1 & 2 & 46 & 4.4 \\
\hline Hydroptilidae & 12 & 6 & 26 & 1 & 2 & 47 & 4.5 \\
\hline Leptoceridae & 25 & 12 & 75 & 3 & 6 & 121 & 11.5 \\
\hline Odontoceridae & 0 & 0 & 1 & 0 & 0 & 1 & 0.1 \\
\hline Philopotamidae & 21 & 0 & 0 & 2 & 1 & 24 & 2.3 \\
\hline Xiphocentronidae & 1 & 0 & 1 & 1 & 0 & 3 & 0.3 \\
\hline Planariidae & 1 & 2 & 0 & 7 & 3 & 13 & 1.2 \\
\hline Total abundance & 340 & 130 & 258 & 120 & 204 & 1052 & 165.1 \\
\hline Total richness & 34 & 26 & 27 & 21 & 35 & 57 & \\
\hline
\end{tabular}


Table 4. Abundance of different taxa collected during the dry season of 2015 and 2016 at the five sampling sites along the Pindo Grande River, Pastaza Province, Ecuador.

\begin{tabular}{|c|c|c|c|c|c|c|c|}
\hline \multirow{2}{*}{ Family } & \multicolumn{7}{|c|}{ Dry season } \\
\hline & M1000 & M500 & MEstación & MPuente & M750a & Total & $\%$ \\
\hline Blattidae & 1 & 0 & 0 & 0 & 0 & 1 & 0.2 \\
\hline Elmidae & 25 & 3 & 2 & 3 & 0 & 33 & 5.1 \\
\hline Psephenidae & 6 & 2 & 0 & 6 & 0 & 14 & 2.2 \\
\hline Ptilodactylidae & 4 & 24 & 2 & 4 & 10 & 44 & 6.8 \\
\hline Chironomidae & 45 & 0 & 2 & 0 & 0 & 47 & 7.3 \\
\hline Simuliidae & 3 & 0 & 0 & 0 & 0 & 3 & 0.5 \\
\hline Tipulidae & 48 & 0 & 2 & 0 & 0 & 50 & 7.8 \\
\hline Baetidae & 100 & 24 & 6 & 4 & 10 & 144 & 22.4 \\
\hline Leptohyphidae & 148 & 24 & 8 & 4 & 10 & 194 & 30.2 \\
\hline Leptophlebiidae & 248 & 48 & 14 & 8 & 20 & 338 & 52.6 \\
\hline Corydalidae & 0 & 0 & 0 & 3 & 0 & 3 & 0.5 \\
\hline Coenagrionidae & 0 & 0 & 0 & 3 & 0 & 3 & 0.5 \\
\hline Libellulidae & 0 & 0 & 0 & 3 & 0 & 3 & 0.5 \\
\hline Megapodagrionidae & 0 & 0 & 0 & 3 & 0 & 3 & 0.5 \\
\hline Platystictidae & 1 & 1 & 0 & 0 & 0 & 2 & 0.3 \\
\hline Polythoridae & 2 & 0 & 2 & 1 & 0 & 5 & 0.8 \\
\hline Perlidae & 6 & 3 & 3 & 0 & 2 & 14 & 2.2 \\
\hline Calamoceratidae & 0 & 2 & 0 & 0 & 2 & 4 & 0.6 \\
\hline Helicopsychidae & 0 & 0 & 1 & 0 & 0 & 1 & 0.2 \\
\hline Hydrobiosidae & 0 & 0 & 1 & 1 & 0 & 2 & 0.3 \\
\hline Hydropsychidae & 0 & 2 & 2 & 1 & 2 & 7 & 1.1 \\
\hline Hydroptilidae & 0 & 2 & 3 & 2 & 2 & 9 & 1.4 \\
\hline Leptoceridae & 0 & 4 & 7 & 4 & 4 & 19 & 3.0 \\
\hline Odontoceridae & 0 & 0 & 0 & 0 & 0 & 0 & 0 \\
\hline Philopotamidae & 44 & 1 & 0 & 0 & 0 & 45 & 7.0 \\
\hline Planariidae & 1 & 7 & 0 & 1 & 1 & 10 & 1.6 \\
\hline Total abundance & 475 & 266 & 105 & 109 & 133 & 1,088 & 169.2 \\
\hline Total richness & 27 & 19 & 14 & 17 & 13 & 38 & 25.0 \\
\hline
\end{tabular}

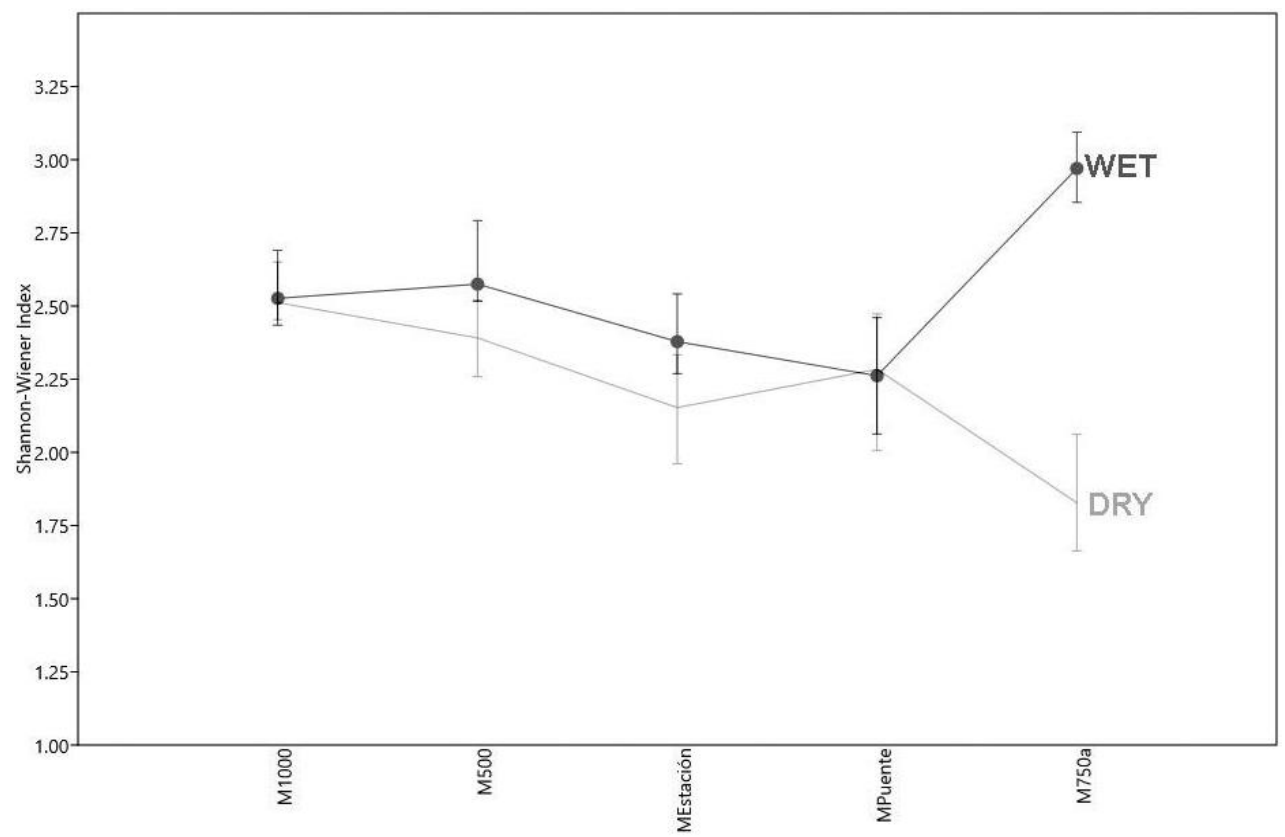

Figure 3. Shannon-Wiener diversity index at the five sampling sites along the Pindo Grande River in the rainy (RS) and dry (DS) seasons of 2014 and 2017. 
The comparison of taxon richness by sampling site and season indicated that M1000 and M500 sites had significantly higher richness in the rainy seasons, than those located downstream of the river in the dry season (MPuente and M750a) $(t=2.9 ; D F=4 ; p<0.05)$ (Tables 3 and 4).

\subsection{Trophic groups}

For predator species, 145 individuals were collected in the rainy season (13.8\%) and 52 $(8.1 \%)$ in the dry season, 734 detritivore individuals $(69.8 \%)$ were collected in the rainy season and 527 individuals $(82.0 \%)$ in the dry season. In the rainy season, 173 individuals $(16.4 \%)$ were classified as herbivores and $64(10.0 \%)$ in the dry season.

\subsection{Water quality assessment by BMWP/Col index}

The macroinvertebrate community at the sampling sites included representative organisms of three water quality classes (Table 5). Most species (15) were recorded in environments with medium-quality water, followed by environments with high-quality (12.2) and poor-quality water (1.2) (Table 5). All sampled sites had high BMWP/Col values, except M750a in the dry season, which exhibited the lowest index value.

Table 5. BMWP/Col index and classification of the five sampling sites along the Pindo Grande River in the rainy and dry seasons.

\begin{tabular}{|c|c|c|c|c|c|c|}
\hline \multicolumn{4}{|c|}{ Rainy season } & \multicolumn{3}{|c|}{ Dry season } \\
\hline Sampling Points & $\begin{array}{l}\mathrm{BMWP} / \mathrm{Col} \\
\text { index }\end{array}$ & Quality & Water condition & $\begin{array}{l}\text { BMWP/Col } \\
\text { index }\end{array}$ & Quality & Status \\
\hline M1000 & 192 & Good & Very clean & 126 & Good & Very clean \\
\hline M500 & 162 & Good & Very clean & 113 & Good & Very clean \\
\hline MEstación & 149 & Good & Very clean & 93 & Acceptable & Slightly contaminated \\
\hline MPuente & 152 & Good & Very clean & 102 & Good & Clean \\
\hline M750a & 152 & Good & Very clean & 67 & Acceptable & Slightly contaminated \\
\hline
\end{tabular}

\subsection{Similarity index and Sorensen's coefficient}

M1000 presented the highest species similarity in aquatic macroinvertebrate communities between the rainy and dry seasons, followed by M500 and MPuente, with values higher than $50 \%$, whereas species similarity at MEstación and M750a was low. M1000 exhibited the highest species similarity in aquatic macroinvertebrate communities between sampling years, followed by M500 and MPuente, with values higher than 50\%, whereas species similarity at MEstación and M750a was low (<50\%).

\section{DISCUSSION}

\subsection{Physicochemical parameters}

Physical-chemical data allowed us to perform and compare variations among sites and seasons using a principal component analysis (PCA). A significant difference could be observed between the points that have higher (MEstation, MPuent, and ME750a) and lower (M1000 and M500) human activity; the same results were found by Rodríguez-Badillo et al. (2016); Parreira de Castro et al. (2018); Macedo et al. (2016) and Selvanayagam and Abril (2016).

The physicochemical parameters $\mathrm{NO}_{3}, \mathrm{COD}, \mathrm{pH}, \mathrm{PO} 4, \mathrm{O} 2$, conductivity, depth and width of the Pindo Grande River were associated with up and downstream fluctuations as result of seasonality, having a significant influence on its macrobenthic community. The same results were found by Selvanayagam and Abril (2016) and by Bojsen and Jacobsen (2003). In freshwater ecosystems such as lakes, rivers and streams, dissolved oxygen concentrations will vary by season, location and water depth. The high concentration of oxygen helps in metabolizing organic matter along the river's journey (Payne, 1986). 


\subsection{Taxon richness, abundance, and diversity}

A different taxon composition was found between the macroinvertebrates collected in wet and dry seasons. These results are in accordance with those obtained by Ríos-Touma et al. (2011), who reported significant differences in the macroinvertebrate community between the rainy and dry seasons, including changes in community composition, richness, abundance, and diversity as result of stochastic variation in the ecosystems.

The number of sensitive morphospecies with strict ecological requirements was higher in the rainy season than in the dry season, in contrast to the findings of Jacobsen and Encalada (1998) and Giacometti and Bersosa (2006), who reported higher species and specimen numbers in the dry season. This difference might be explained by the fact that these studies were conducted in different ecological areas, and the diversity and abundance of macroinvertebrates are known to be associated with the riverine vegetation of the sampled area (Righi-Cavallaro Ocampo et al., 2010).

Shannon-Wiener indices tended to decrease between the sites M1000 and MPuente, which may be due to changes in variables such as $\mathrm{PO}_{4}$ and $\mathrm{O}_{2}$ concentrations, conductivity, and COD, as shown by the PCA. The sampling sites were clustered based on species distribution (upstream and downstream) and anthropogenic activity, in which the latter may result in less favorable environmental conditions for macroinvertebrate development (Hinojosa-Garro et al., 2010). Changes in water quality could modify species composition, particularly those that are sensitive to pollution (Rodriguéz-Badillo et al., 2016). In contrast, several morphospecies, including members of Chironomidae, Hexatoma spp., and Parapoynx spp., are known to benefit from environmental changes and/or anthropogenic disturbance (Mykrä and Heino, 2017), as it was observed in the M750a and Mpuente sites.

\subsection{Trophic groups}

In healthy aquatic ecosystems, detritivores predominate, followed by herbivores and predators (Chará-Serna et al., 2010; Barrios et al., 2015). Of these trophic categories, detritivores were the most abundant at all sampling sites in the present study. Therefore, the study area can be considered to be in a healthy condition (Cummins et al., 2005; Jyväsjärvi et $a l ., 2013)$. This could be because there still are forested areas at the riverbank of Pindo Grande River, and according to Bojsen and Jacobsen (2003) the vegetation cover contributes to have a good macroinvertebrate community.

\subsection{Water quality assessment by BMWP/Col index}

All sampled sites had high BMWP/Col values, except M750a in the dry season, which exhibited the lowest index value. These values, along with the analysis of sensitivity to pollution and/or environmental disturbance, indicated that the BMWP/Col index did not reflect the real conditions prevalent at the collection sites. This may be due to the fact that in the BMWP/Col index, organisms are identified to the family level, and variations in the tolerance of taxa within the same family are unknown (Bispo et al., 2002; Bonada et al., 2004; Tomanova and Tedesco, 2007; Domínguez and Fernández, 2009; Forero et al., 2014).

The sites with the highest BMWP/Col index were M1000 and M500, which were characterized by the presence of diverse communities consisting of sensitive organisms with strict ecological requirements, such as Anacroneuria spp. In contrast, MEstación had the lowest index within the category, probably owing to the direct influence of water collection activities, which may affect the substrate, water flow, and aquatic vegetation in the area. However, this site was classified as healthy, based on the observations made in the two seasons, suggesting that environmental disturbances were punctual and associated with climatic conditions, or that this index did not reflect these disturbances.

Site MPuente presented a less diverse macrobenthic community dominated by organisms 
tolerant to habitat changes. However, these changes were not significant because the BMWP/Col index indicated good environmental quality, despite the anthropic activities prevalent in adjoining areas. This result is consistent with that of Carrera and Fierro (2001), Terneus et al. (2012), and Abril et al. (2015).

Although the macroinvertebrate community was well characterized in the present study, inter-annual samplings are necessary to determine species changes due to variations in ecological flow, variations in environmental conditions and anthropogenic impacts prevalent in this lotic system (Jacobsen, 2003; Encalada and Ríos, 2011; Ríos-Touma et al., 2012).

\section{CONCLUSIONS}

The study found that the water quality of the Pindo Grande River is in good condition and exhibited ideal characteristics to develop epibenthic communities, resulting from welloxygenated streams with different substrates; however, these habitats seem to be gradually affected by anthropogenic activities, according to the PCA carried out, which classified the data into two clusters due to anthropic influence observed in the river.

The physical and chemical parameters that most influenced the macroinvertebrate community in the Pindo Grande River were $\mathrm{NO}_{3}, \mathrm{COD}, \mathrm{pH}, \mathrm{PO}_{4}, \mathrm{O}_{2}$, conductivity, depth and width. It could also be observed as an influence of dry and rainy seasons; finding lower water quality in the dry season at point M750a; these results are consistent with Encalada and Rios (2011). It is necessary to carry out systematic sampling campaigns to establish a monitoring strategy in this important biological area of Ecuador.

It is recommended that the biotic index BMWP/Col be used in the Ecuadorian Amazon Region; however, caution needs to be taken with those cosmopolitan abundant species that might interfere with the index values in this ecological region of Ecuador.

\section{ACKNOWLEDGEMENTS}

This research was funded by the UTE University (Project Number 007-2014-IC-FAUDPAP-MAE).

\section{REFERENCES}

ABARCA MORALES, H. El uso de macroinvertebrados como bioindicadores de la calidad de agua. Biocenosis, v. 20, p. 1-2, 2007.

ABRIL, R.; RODRÍGUEZ, L.; PUALACÍN, R. L.; SALAZAR, J. S. Impactos ambientales generados por el dique del río Pindo en Shell cantón Mera. Revista Amazónica Ciencia y Tecnología, v. 3, n 3, p. 258-283, 2015.

ARROYO, C.; ENCALADA, A. C. Evaluación de la calidad de agua a través de macroinvertebrados bentónicos e índices biológicos en ríos tropicales en bosque de neblina montano. ACI Avances en Ciencias e Ingenierías, v. 1, n. 1, 2009. https://doi.org/10.18272/aci.v1i1.4

BARRIOS, M.; RODRÍGUEZ-OLARTE, D.; GARCÍA E. Índice de integridad de los ecosistemas fluviales con base a las comunidades de insectos acuáticos en el río Misoa de la cuenca del lago de Maracaibo, Venezuela. Entomotropica, v. 30, n. 8, p. 69-83, 2015.

BISPO, P. C.; FROEHLICH, C. G.; OLIVEIRA, L. G. Spatial distribution of Plecoptera nymphs in streams of a mountainous area of Central Brazil. Brazilian Journal of Biology, v. 62, n. 3, p. 409-417, 2002. https://doi.org/10.1590/S1519-69842002000300003 
BOJSEN, B. H.; JACOBSEN, D. Effects of deforestation on macroinvertebrate diversity and assemblage structure in Ecuadorian Amazon streams. Hydrobiologie, v. 158, n. 3, p. 317-342, 2003. https://doi.org/10.1127/0003-9136/2003/0158-0317

BONADA, N.; ZAMORA-MUÑOZ, C.; RIERADEVALL, M.; PRAT, N. Trichoptera (Insecta) collected in Mediterranean River basins of the Iberian Peninsula: Taxonomic remarks and notes on ecology. Graellsia, v. 60, n. 1, p. 41-69, 2004.

CHARÁ-SERNA, A.; CHARÁ, J.; ZÚÑIGA, M.; PEDRAZA, G.; GIRALDO, L. Clasificación trófica de insectos acuáticos en ocho quebradas protegidas de la ecorregión cafetera colombiana. Universitas Scientiarium, v. 15, n. 1, p. 27-36, 2010.

CARRERA, C.; FIERRO, K. Manual de monitoreo los macroinvertebrados acuáticos como indicadores de la calidad del agua. Quito: EcoCiencia Publishers, 2001. 67 p.

COVICH, A. Geographical and Historical Comparisons of Neotropical Streams: Biotic Diversity and Detrital Processing in Highly Variable Habitats. Journal of the North American Benthological Society, v. 7, n. 9, p. 361-386, 1988. https://doi.org/10.2307/1467297

CUMMINS, K. W.; MERRITT, R. W.; ANDRADE, P. C. N. The use of invertebrate functional groups to characterize ecosystem attributes in selected streams and rivers in southeast Brazil. Studies on Neotropical Fauna and Environment, v. 40, n. 1, p. 71-90, 2005. https://doi.org/10.1080/01650520400025720

DOMÍNGUEZ, E.; FERNÁNDEZ, H. R. Macroinvertebrados bentónicos sudamericanos, Sistemática y Biología. Tucumán: Fundación Miguel Lillo Publishers, 2009. 656 p.

ENCALADA, A.; RÍOS, B. Aprendizaje de las cuencas altoandinas: Proyecto FUCARA: Quito: Laboratorio de Ecología Acuática; USFQ Publishers, 2011.

FERnÁnDEZ, H.; DOMÍNGUEZ, E. Guía para la Determinación de los Artrópodos Bentónicos Sudamericanos. Tucumán: Universitaria de Tucumán Publishers, 2001. 282 p.

FORERO, L.; LONGO, M.; RAMÍREZ, J.; CHALAR, G. Índice de calidad ecológica con base en macroinvertebrados acuáticos para la cuenca del río Negro (ICERN-MAE), Colombia. Revista Biología Tropical, v. 62, n. 2, p. 233-247, 2014.

GARIE, H.; MCINTOSH, A. Distribution of benthic macroinvertebrates in a stream exposed to urban runoff. Journal of the American Water Resources Association, v. 22, n. 3, p. 447-455, 1986. https://doi.org/10.1111/j.1752-1688.1986.tb01899.x

GIACOMETTI, J. C.; BERSOSA, F. Macroinvertebrados acuáticos y su importancia como bioindicadores de calidad del agua en el río Alambi. Boletín Técnico, Serie Zoologica, v. 6, p. 17-32, 2006.

HAMADA, N.; NESSIMIAN, J.; QUERINO, R. Insetos aquáticos na Amazônia brasileira: taxonomia, biologia e ecologia. Manaus: INPA, 2014. $711 \mathrm{p}$.

HINOJOSA-GARRO, D.; MASON, F.; UNDERWOOD, J. C. Effects of macrophyte spatial architecture on periphyton and macroinvertebrate community structure in shallow water bodies under contrasting land management. Fundamental and Applied Limnology, v. 177, n. 1, p. 19-37, 2010 
JACOBSEN, D.; ENCALADA, A. The macroinvertebrate fauna of Ecuadorian Highland streams in the wet and dry seasons. Archiv für Hidrobiologie, v. 142, n. 1, p. 53-70, 1998.

JACOBSEN, D. Altitudinal changes in diversity of macroinvertebrates from small streams in the Ecuadorian Andes. Archiv für Hydrobiologie, v. 158, n. 2, p. 145-167, 2003.

JYVÄSJÄRVI, J.; BOROS, G.; JONES, R. I.; HÄMÄLÄINEN, H. The importance of sedimenting organic matter, relative to oxygen and temperature, in structuring lake profundal macroinvertebrate assemblages. Hydrobiologia, v. 709, n. 1, p. 55-72, 2013. https://doi.org/10.1007/s10750-012-1434-0

KHATRI, N.; TYAGI, S. Influences of natural and anthropogenic factors on surface and groundwater quality in rural and urban areas. Frontiers in Life Science, v. 8, n. 1, p. 23 39, 2015. https://dx.doi.org/10.1080/21553769.2014.933716

LÓPEZ-LÓPEZ, E., SEDEÑO-DÍAZ, J. E. Biological Indicators of Water Quality: The Role of Fish and Macroinvertebrates as Indicators of Water Quality. In: ARMON, R.; HÄNNINEN, O. (eds.). Environmental Indicators. Dordrecht: Springer, 2015. https://doi.org/10.1007/978-94-017-9499-2_37

MACEDO, D. R.; HUGHES, R. M.; FERREIRA, W. R.; FIRMIANO, K. R.; SILVA, D. R. O.; LIGEIRO, R.; KAUFMANN P. R.; CALLISTO, M. Development of a benthic macroinvertebrate multimetric index (MMI) for Neotropical Savanna headwater streams. $\begin{array}{llllll}\text { Ecological Indicators, } & \text { v. 64, } & \text { p. }\end{array}$ https://doi.org/10.1016/j.ecolind.2015.12.019

MAGURRAN, A. E. Ecological diversity and its measurement. New Jersey: Princeton University Press, 1988. p. 179.

MERRITT, R.; CUMMINS, K.; BERG, M. An introduction to the aquatic insects of North America. USA: Kendall/Hunt, 2008. 1158 p.

MORENO, C. E. Métodos para medir la Biodiversidad. Zaragoza: M\&T-Manuales y Tesis SEA, 2001. vol. 1. 84 p.

MUZAFFAR, S.; COLBO, M. The effects of sampling technique on the ecological characterization of shallow, benthic macroinvertebrate communities in two Newfoundland ponds. Hidrobiología, v. 477, n. 1-3, p. 31-39, 2002. https://doi.org/10.1023/A:1021008526284

MYKRÄ, H.; HEINO, J. Decreased habitat specialization in macroinvertebrate assemblages in anthropogenically disturbed streams. Ecological Complexity, v. 31, p. 181-188, 2017. https://doi.org/10.1016/j.ecocom.2017.07.002

PARREIRA DE CASTRO D.; DOLÉDEC, S.; CALLISTO, M. Land cover disturbance homogenizes aquatic insect functional structure in neotropical savanna streams. $\begin{array}{llllll}\text { Ecological Indicators, } & \text { v. } & \text { 84, } & \text { p. } & \text { 573-582, }\end{array}$ https://doi.org/10.1016/j.ecolind.2017.09.030

PASTAZA. Gobierno Autónomo Descentralizado. Plan de desarrollo y ordenamiento territorial de la Provincia de Pastaza al año 2025. Actualización 2015. Pastaza, 2015. $217 \mathrm{p}$.

PAYNE, A. I. The ecology of tropical lakes and rivers. Washington, DC.: OSTI, 1986. 
PLAFKIN, J. L.; BARBOUR, M. T.; PORTER, K. D.; GROSS, S. K.; HUGHES, R. M. Rapid bioassessment protocols for use in streams and rivers: benthic macroinvertebrates and fish. EPA v. 444. Washington, DC: USEPA Office of Water, 1989. p. 4-89- 001.

RAGEOT, R.; ALBUJA, L. Mamíferos de un sector de la Alta Amazonía Ecuatoriana (Mera, Provincia de Pastaza). Politécnica, v. 19, n. 2, p. 165-208, 1994.

REICE, S. R.; WISSMAR, R. C.; NAIMAN, R. J. Disturbance regimes, resilience, and recovery of animal communities and habitats in lotic ecosystems. Environmental Management, v. 14, p. 647-659, 1990. https://doi.org/10.1007/BF02394715

RIGHI-CAVALLARO OCAMPO, K.; SPIES, M. R.; SIEGLOCH, A. E. Composição da fauna de Ephemeroptera, Plecoptera e Trichoptera na bacia do Rio Miranda, Estado do Mato Grosso do Sul, Brasil. Biota Neotropica, v. 10, n. 2, p. 253-260, 2010. https://dx.doi.org/10.1590/S1676-06032010000200028

RÍOS, M.; BORGTOFT, P. Las Plantas y el Hombre: Memorias del Primer Simposio Ecuatoriano de Etnobotánica y Botánica Económica. Quito: Abya Yala, 1994. 436 p.

RÍOS-TOUMA, B.; ENCALADA, A. C.; PRAT, N. Macroinvertebrate assemblages of an Andean high-altitude tropical stream: the importance of season and flow. International review of hydrobiology, v. 96, n. 6, p. 667-685, 2011. https://doi.org/10.1002/iroh.201111342

RÍOS-TOUMA, B.; PRAT, N.; ENCALADA, A. C. Invertebrate drift and colonization processes in a tropical Andean stream. Aquatic Biology, v. 14, n. 3, p. 233-246, 2012. https://doi.org/10.3354/ab00399

RIVAS, J. Análisis preliminar de los servicios ecosistémicos de la cuenca media del río Pastaza, Ecuador. 2015. (Unpublished Bachelor's thesis) Pontificia Universidad Católica del Ecuador, Quito, 2015.

RODRÍGUEZ-BADILLO, L.; RÍOS-GUAYASAMÍN, P.; ESPINOSA-CHICO, M.; CEDEÑO, P.; JIMÉNEZ, G. Water quality characterization of benthonic macroinvertebrates of Puyo river, Ecuadorian Amazonia. Hidrobiologica, v. 26, n. 3, p. 497-507, 2016.

ROLDÁN, G. Guía para el Estudio de los Macroinvertebrados Acuáticos del Departamento de Antioquia. Bogotá: Presencia, 1988. 228 p.

ROLDÁN, G. Bioindicación de la calidad de agua en Colombia: uso del método BMWP/Col. Colombia: Universidad de Antioquia, 2003. 170 p.

SALLES, F. As Ninfas de Ephemeroptera (Insecta) ocurrentes no Brasil. Tese (Programa de Post grado en Entomología para obtención del Título de Doctor en Ciencias) Universidade Federal de Viçosa, Viçosa, 2006.

SELVANAYAGAM, M. Use of Benthic Macro Invertebrates as a Biological Indicator in Assessing Water Quality of River Puyo, Puyo, Pastaza, Ecuador. American Journal of Life Sciences, v. 4, n. 1, p. 1, 2016. https://doi.org/10.11648/j.ajls.20160401.11

SELVANAYAGAM, M.; ABRIL, R. Water Quality Assessment of Piatua River Using Macroinvertebrates in Puyo, Pastaza, Ecuador. American Journal of Life Sciences, v. 3, n. 3, p. 167, 2015. https://doi.org/10.11648/j.ajls.20150303.17 
STANFORD, J. A.; WARD, J. V. Insect Species Diversity as a Function of Environmental Variability and Disturbance in Stream Systems. In: BARNES, J. R.; MINSHALL, G. W. (eds.). Stream Ecology. Boston: Springer, 1983. https://doi.org/10.1007/978-1-46133775-1_11

TERNEUS, E.; RACINES, M. J.; HERNÁNDEZ, K. Evaluación ecológica del Río Lliquino a través de macroinvertebrados acuáticos, Pastaza-Ecuador. Revista de Ciencias, v. 16, p. 31-45, 2012.

TORRES, V. Centro de interpretación y senderos Zuma Huasi. (Bachelor's Thesis) Universidad de Especialidades Turísticas, Quito, 2006.

TOMANOVA, S.; TEDESCO, P. Tamaño corporal, tolerancia ecológica y potencial de bioindicación de la calidad del agua de Anacroneuria spp. (Plecoptera: Perlidae) en América del Sur. Revista de Biología Tropical, v. 55, n. 1, p. 67-81, 2007.

UNIVERSIDAD TECNOLÓGICA EQUINOCCIAL. Estación Biológica Pindo Mirador. Quito: Gráficas Iberia, 2015. 131p.

VINUEZA, M. Utilización de macroinvertebrados y parámetros físicoquímicos para evaluaciones ecológicas en ecosistemas acuáticos de la Estación Biológica Pindo Mirador. (Bachelor's thesis) Universidad Tecnológica Equinoccial, Quito, 2017.

WALTEROS-RODRÍGUEZ，J. M.; PAIBA-ALZATE，J. E. Estudio preliminar de la comunidad de macroinvertebrados acuáticos en la Reserva Forestal Torre Cuatro. Boletín Científico. Centro de Museos. Museo de Historia Natural, v. 14, n. 1, p. 137-149, 2010. 